Article

\title{
Chemical Composition, Antifungal and Insecticidal Activities of the Essential Oils from Tunisian Clinopodium nepeta subsp. nepeta and Clinopodium nepeta subsp. glandulosum
}

\author{
Haïfa Debbabi ${ }^{1}$, Ridha El Mokni $\left.{ }^{2,3,4}{ }^{(}\right)$, Ikbal Chaieb ${ }^{5}$, Simona Nardoni ${ }^{6}\left(\mathbb{D}\right.$, Filippo Maggi ${ }^{7}(\mathbb{D}$, \\ Giovanni Caprioli ${ }^{7, *(D)}$ and Saoussen Hammami ${ }^{1}$ (D) \\ 1 Research Unit 13ES63, Applied Chemistry and Environment, Faculty of Sciences of Monastir, \\ University of Monastir, 5000 Monastir, Tunisia; debbabi_haifa10@hotmail.com (H.D.); \\ h_saoussen@yahoo.fr (S.H.) \\ 2 Department Pharmaceutical Sciences "A", Laboratory of Botany, Cryptogamy and Plant Biology, \\ Faculty of Pharmacy of Monastir BP 207, Avenue Avicenna, University of Monastir, 5000 Monastir, Tunisia; \\ riridah@yahoo.fr \\ 3 Department of Silvo-Pastoral Resources, Laboratory of Research in Silvo-Pastoral Resources, \\ Silvo-Pastoral Institute of Tabarka, BP. 345, University of Jendouba, Tabarka 8110, Tunisia \\ 4 IRESA, Laboratory of Forest Ecology, I.N.R.G.R.E.F, BP Nº10, Ariana 2080, Tunisia \\ 5 Research unit UR13AGR09, Regional Center for Research in Horticulture and Organic Agriculture, \\ Chott Mariem, University of Sousse, TN-4042 Sousse, Tunisia; ikbal_c@yahoo.fr \\ 6 Department of Veterinary Sciences, Università degli Studi di Pisa, 56124 Pisa, Italy; simona.nardoni@unipi.it \\ 7 School of Pharmacy, University of Camerino, 62032 Camerino, Italy; filippo.maggi@unicam.it \\ * Correspondence: giovanni.caprioli@unicam.it
}

Academic Editor: Giovanni Benelli

Received: 9 April 2020; Accepted: 1 May 2020; Published: 2 May 2020

\begin{abstract}
The present investigation was focused on the study of the chemical composition variability and biological activities of the essential oils from Clinopodium nepeta subsp. nepeta and subsp. glandulosum. Essential oils extraction was performed using hydrodistillation and the separation of the constituents was carried out by gas chromatography coupled with mass spectrometry (GC-MS). Antifungal activities were tested against Aspergillus flavus, Aspergillus terreus, Microsporum canis, Microsporum gypseum, Trichophyton mentagrophytes, and Candida albicans. Toxicity and repellency were evaluated against the stored product pests Tribolium confusum and Sitophilus zeamais. Both essential oils were characterized by a high content of oxygenated monoterpenes. Piperitone ranks first in the subspecies nepeta and piperitenone oxide is the dominant constituent in the subspecies glandulosum. All tested samples displayed noteworthy antifungal properties, with the highest activity observed for the essential oil of $C$. nepeta subsp. glandulosum, collected in Béni-M'tir, against T. mentagrophytes $(\mathrm{MIC}=40 \mu \mathrm{g} / \mathrm{mL}$ ). The essential oil samples of $C$. nepeta subsp. glandulosum were strongly repellent to the insect species ( $\mathrm{PR}>80 \%$, after $2 \mathrm{~h}$ ) and highly toxic to $\mathrm{S}$. zeamais reaching $97.5 \%-100 \%$ mortality after $24 \mathrm{~h}$ of exposure. In conclusion, this study showed considerable intra-specific changes in the quality of $C$. nepeta essential oils, which is reflected in different rates of antifungal and insecticidal activity.
\end{abstract}

Keywords: Lamiaceae; Clinopodium nepeta subsp. nepeta; Clinopodium nepeta subsp. glandulosum; essential oils; chemical variability; biological activities

\section{Introduction}

All across the globe, environmental problems such as soil and water pollution and food contamination are continuously increasing, inducing many disasters and human tragedies. 
The excessive and indiscriminate use of available pesticides to control the losses of stored crops and to reduce insect-borne diseases as malaria, filaria and trypanosomiasis induced disturbances in ecosystem functioning [1,2]. Moreover, synthetic fungicides and fungal-drugs utilization to treat environmental and animal molds are not in a lesser class, when we talk about the negative effects and the appearance of fungicide-resistant pathogens [3,4]. Therefore, there is an increasing concern to search for new highly selective and eco-friendly alternatives of beneficial pest control materials to feed the growing human population in a healthy environment. Medicinal plants produce an arsenal of chemical compounds that alleviate various illnesses and rebalance human health. Much attention has been focused on the study of plant extracts and essential oils due to their pivotal role as a source of phototherapeutics widely used to fight infectious diseases [5,6]. Natural insecticides, fungicides and herbicides with promising effects have the properties to supplant or replace synthetic organic pesticides and therefore to avoid environmental contamination. Hence, various applications of essential oils acting as safe fungicidal agents against a large number of molds and as environmentally friendly insecticides have been reported $[7,8]$. It is noteworthy that the biosynthesis and accumulation of phytochemicals by medicinal herbs are influenced by environmental circumstances including temperature, climate, light and the region altitude [9]. According to the harvesting time and the environment in which they are found, the same plant species or subspecies may present different chemical compositions of essential oils [10]. Importantly, the nature of the produced secondary metabolites and essential oils influences the mechanisms of actions and determines the medicinal and economic utility of various plants. In this context, differences in essential oils productivity, including an increase or decrease in the yields, and variation of the chemical composition depending on harvesting phase (vegetative, pre-flowering, flowering and fruiting), as well as the plant geographical origin have been previously investigated [11,12].

The genus Clinopodium (Lamiaceae family) consists of 135 perennial herbs, most of them being rich sources of essential oils, distributed widely in Southern Europe, western Asia and all around the Mediterranean area [13]. Many preclinical studies have demonstrated the inhibitory effects of Clinopodium essential oils towards various bacterial and fungal strains. Their insecticidal properties have also been reported [14-17]. Among various Clinopodium species, Clinopodium nepeta L. Kuntze (Syn. Calamintha nepeta L. Kuntze) is apolymorphic and a fragrant plant that has been used traditionally around the world as an important antispasmodic, diaphoretic, stimulant, and tonic medicinal herb; it is also considered as a mint-like spice and is used in various culinary recipes [18,19]. A literature survey of the chemical investigation of essential oils produced by C. nepeta revealed the high content in oxygenated monoterpenes. Most of the phytochemical and biological studies on C. nepeta did not concern the level of subspecies [20]. However, some authors take this parameter into consideration during analysis. As a consequence, the presence of remarkable variations among the major constituents of various subspecies was distinguished [21]. Their biological features have also been well-confirmed [22,23]. Thus, antimicrobial, anti-Candida, antioxidant and insecticidal activities of C. nepeta subsp. glandulosum (Req.) Govaerts essential oils from Montenegro, Turkey, Italy, and Croatia have been reported [24-28].

Since antiquity, the essential oils from C. nepeta subsp. nepeta leaves have been used as a fragrance and insect repellent [29]. The essential oils from the subspecies collected in Portugal, Serbia and Italy have been characterized for antifungal, antiproliferative, antioxidant, and antimicrobial effects [30-33]. In Tunisia only two subspecies, namely C. nepeta subsp. nepeta and C. $n$. subsp. glandulosum have been reported up to now; they have a very attractive smell and are often visited by insect pollinators. As far as we know, nothing is reported on the chemical profile and biological efficacy of their essential oils.

The aim of this paper was to compare the phytochemical profile and to test the biological efficiency of the essential oils extracted from C. nepeta subsp. nepeta and C. nepeta subsp. glandulosum growing in different localities in North and North-western Tunisia (Table 1). A comprehensive evaluation of the antifungal and insecticidal activities was investigated considering the chemical variability depending on the subspecies and the geographical origin. The main objective of this study was to search for 
environmentally friendly insecticides and antifungals that are readily biodegradable, with minimal toxic effects on health and environment and which can be marketed at premium prices.

Table 1. Locality/Harvesting place, harvesting period and voucher specimen reference of both Clinopodium nepeta subspecies.

\begin{tabular}{|c|c|c|c|c|}
\hline Taxon & $\begin{array}{c}\text { Species } \\
\text { Abbreviation }\end{array}$ & $\begin{array}{l}\text { Harvesting } \\
\text { Place }\end{array}$ & $\begin{array}{l}\text { Harvesting } \\
\text { Period (2016) }\end{array}$ & Voucher Specimen \\
\hline $\begin{array}{l}\text { Clinopodium nepeta (L.) } \\
\text { Kuntze subsp. nepeta }\end{array}$ & $\mathrm{CNN}$ & Béni-M'tir & October & $\begin{array}{c}\text { [LAM./Cal.n.n./ } \\
\text { Kroumiria/BM.13/ } \\
\text { 27102016] }\end{array}$ \\
\hline $\begin{array}{c}\text { Clinopodium nepeta subsp. } \\
\text { glandulosum (Req.) } \\
\text { Govaerts }\end{array}$ & $\mathrm{CNG}_{1}$ & Béni-M'tir & October & $\begin{array}{l}\text { [LAM./Cal.n.g./ } \\
\text { Kroumiria/BM.25/ } \\
\text { 27102016] }\end{array}$ \\
\hline $\begin{array}{c}\text { Clinopodium nepeta subsp. } \\
\text { glandulosum (Req.) } \\
\text { Govaerts }\end{array}$ & $\mathrm{CNG}_{2}$ & Bizerte & July & $\begin{array}{l}\text { [LAM./Cal.n.g./ } \\
\text { NE/Bizerta. 03/ } \\
\text { 10082016] }\end{array}$ \\
\hline
\end{tabular}

\section{Results}

\subsection{Chemical Profiles of Essential Oils}

The hydrodistillation of dry plant materials yielded $1.21 \%, 0.93 \%$ and $0.84 \%$ of essential oils, for Clinopodium nepeta subsp. nepeta (CNN), Clinopodium nepeta subsp. glandulosum from Béni-M'tir $\left(\mathrm{CNG}_{1}\right)$, and Clinopodium nepeta subsp. glandulosum from Bizerta $\left(\mathrm{CNG}_{2}\right)$, respectively. The percent occurrence of the oil phytochemicals, elucidated through GC-MS, is summarized in Table 2.

Table 2. Chemical profiles of essential oils obtained from Clinopodium nepeta subspecies harvested from different localities.

\begin{tabular}{|c|c|c|c|c|c|c|}
\hline \multirow[t]{2}{*}{ No. } & \multirow[t]{2}{*}{ RI Calc } & \multirow[t]{2}{*}{ RI LIT } & \multirow[t]{2}{*}{ Compounds } & \multicolumn{3}{|c|}{ Content (\%) } \\
\hline & & & & $\mathrm{CNN}$ & $\mathrm{CNG}_{1}$ & $\mathrm{CNG}_{2}$ \\
\hline 1 & 932 & 932 & $\alpha$-Pinene & 0.23 & 0.2 & 0.1 \\
\hline 2 & 975 & 974 & $\beta$-Pinene & 0.3 & 0.3 & 0.1 \\
\hline 3 & 991 & 988 & Myrcene & - & 0.1 & $\operatorname{tr}$ \\
\hline 4 & 995 & 994 & 3-Octanol & 0.6 & 0.7 & 0.7 \\
\hline 5 & 1000 & 1000 & Decane & $\operatorname{tr}$ & - & \\
\hline 6 & 1024 & 1024 & $o$-Cymene & & & $\operatorname{tr}$ \\
\hline 7 & 1024 & 1022 & p-Cymene & - & 0.3 & - \\
\hline 8 & 1028 & 1024 & Limonene & 1.9 & 4.2 & 1.4 \\
\hline 9 & 1030 & 1026 & 1,8-cineole & 0.4 & 0.2 & 0.1 \\
\hline 10 & 1058 & 1054 & $\gamma$-Terpinene & $\operatorname{tr}$ & 0.2 & $\operatorname{tr}$ \\
\hline 11 & 1066 & 1070 & cis-4-Thujanol & - & 0.1 & - \\
\hline 12 & 1100 & 1095 & Linalool & 0.7 & 0.6 & 0.5 \\
\hline 13 & 1120 & 1119 & trans- $p$-Mentha-2,8-dien-1-ol & - & 0.1 & $\operatorname{tr}$ \\
\hline 14 & 1164 & 1165 & Borneol & - & 0.3 & 0.4 \\
\hline 15 & 1176 & 1174 & Terpinen-4-ol & - & 1.1 & 0.1 \\
\hline 16 & 1184 & 1179 & $p$-Cymen-8-ol & - & 0.6 & 0.2 \\
\hline 17 & 1189 & 1186 & $\alpha$-Terpineol & 0.4 & 0.4 & 0.4 \\
\hline 18 & 1197 & 1196 & Methyl chavicol & - & 0.3 & - \\
\hline 19 & 1211 & 1220 & 4,7-dimethylbenzofuran & - & 0.2 & $\operatorname{tr}$ \\
\hline 20 & 1215 & 1221 & 8,9-Dehydrothymol & - & 0.3 & 0.4 \\
\hline 21 & 1239 & 1238 & Cumin aldehyde & - & 2.0 & 0.1 \\
\hline 22 & 1243 & 1239 & Carvone & - & 0.2 & $\operatorname{tr}$ \\
\hline 23 & 1253 & 1249 & Piperitone & - & - & 19.5 \\
\hline 24 & 1255 & 1253 & Piperitone oxide & 51.7 & 23.5 & 16.3 \\
\hline 25 & 1268 & 1274 & Pseudodiosphenol & - & - & 0.2 \\
\hline 26 & 1271 & $1277^{\mathrm{a}}$ & $p$-Mentha-1,8-dien-3-one & - & 0.5 & 0.6 \\
\hline 27 & 1286 & 1287 & Bornyl acetate & 0.3 & 0.3 & 0.2 \\
\hline 28 & 1289 & 1298 & $p$-Mentha-1,4-dien-7-al & - & 1.0 & 0.2 \\
\hline 29 & 1292 & 1289 & Thymol & 3.6 & 1.6 & 4.0 \\
\hline 30 & 1299 & 1305 & Diosphenol & 0.6 & - & 1.1 \\
\hline
\end{tabular}


Table 2. Cont

\begin{tabular}{|c|c|c|c|c|c|c|}
\hline \multirow[t]{2}{*}{ No. } & \multirow[t]{2}{*}{ RI Calc } & \multirow[t]{2}{*}{ RI LIT } & \multirow[t]{2}{*}{ Compounds } & \multicolumn{3}{|c|}{ Content (\%) } \\
\hline & & & & $\mathrm{CNN}$ & $\mathrm{CNG}_{1}$ & $\mathrm{CNG}_{2}$ \\
\hline 31 & 1302 & 1308 & 6-Hydroxycarvotanacetone & 0.7 & 5.1 & 1.2 \\
\hline 32 & 1340 & 1340 & Piperitenone & 0.2 & 0.4 & 0.5 \\
\hline 33 & 1366 & 1366 & Piperitenone oxide & 23.4 & 39.3 & 27.8 \\
\hline 34 & 1376 & 1374 & $\alpha$-Copaene & - & 0.6 & 0.3 \\
\hline 35 & 1385 & 1387 & $\beta$-Bourbonene & - & 0.4 & 0.2 \\
\hline 36 & 1400 & 1400 & Tetradecane & 0.2 & 0.9 & 1.8 \\
\hline 37 & 1419 & 1417 & (E)-Caryophyllene & 0.3 & 1.4 & 0.6 \\
\hline 38 & 1454 & 1452 & $\alpha$-Humulene & $\operatorname{tr}$ & 0.1 & $\operatorname{tr}$ \\
\hline 39 & 1458 & 1454 & (E)- $\beta$-Farnesene & - & 0.1 & $\operatorname{tr}$ \\
\hline 40 & 1481 & 1484 & Germacrene D & - & 0.3 & $\operatorname{tr}$ \\
\hline 41 & 1524 & 1522 & $\delta$-Cadinene & - & 0.2 & $\operatorname{tr}$ \\
\hline 42 & 1578 & 1577 & Spathulenol & $\operatorname{tr}$ & - & 0.2 \\
\hline 43 & 1583 & 1582 & Caryophyllene oxide & 2.0 & 2.7 & 2.3 \\
\hline 44 & 1600 & 1600 & Hexadecane & - & $\operatorname{tr}$ & - \\
\hline 45 & 1613 & 1608 & Humulene epoxide II & $\operatorname{tr}$ & 0.2 & 0.2 \\
\hline 46 & 1689 & 1687 & Eudesma-4(15),7-dien-1 $\beta$-ol & - & 0.3 & 0.2 \\
\hline 47 & 1848 & 1844 & Phytone & $\operatorname{tr}$ & - & $\operatorname{tr}$ \\
\hline \multicolumn{3}{|c|}{ Oxygenated monoterpenes } & & 82.0 & 77.6 & 73.4 \\
\hline \multicolumn{3}{|c|}{ Monoterpene hydrocarbons } & & 2.5 & 5.3 & 2.3 \\
\hline \multicolumn{3}{|c|}{ Oxygenated sesquiterpenes } & & 2.1 & 3.1 & 2.8 \\
\hline \multicolumn{3}{|c|}{ Sesquiterpene hydrocarbons } & & 0.4 & 3.1 & 1.2 \\
\hline \multicolumn{3}{|c|}{ Others } & & 1.0 & 2.1 & 2.7 \\
\hline \multicolumn{3}{|c|}{ Total identified components } & & 88.0 & 91.2 & 82.4 \\
\hline
\end{tabular}

RI Calc: linear retention index calculated against homologue series of $\mathrm{C}_{8}-\mathrm{C}_{30}$ alkanes. RI LIT: RI taken from Adams

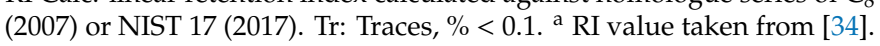

As shown, 24, 40 and 42 components were identified and quantified in $\mathrm{CNN}, \mathrm{CNG}_{1}$ and $\mathrm{CNG}_{2}$ essential oils accounting for $88.0 \%, 91.2 \%$ and $82.4 \%$ of the total compositions, respectively. Oxygenated monoterpenes constituted the main groups in $\mathrm{CNN}(82.0 \%), \mathrm{CNG}_{1}(77.6 \%)$ and $\mathrm{CNG}_{2}(73.4 \%)$ essential oils of the selected Lamiaceae plants. It is worth noting that piperitone oxide and piperitenone oxide were identified as the most abundant components in the volatile oils of $\mathrm{CNN}(51.7 \%$ and $23.4 \%), \mathrm{CNG}_{1}$ (23.5\% and $39.3 \%)$ and $\mathrm{CNG}_{2}(16.3 \%$ and $27.8 \%)$. While the oxygenated monoterpene piperitone was found in high levels (19.5\%) only in $\mathrm{CNG}_{2}$ (Table 2).

\subsection{In Vitro Antifungal Activity of Essential Oils}

The anti-fungal activity of the selected essential oils was screened against potentially pathogenic fungi in humans and animals, namely A. flavus, A. terreus, C. albicans, M. canis, M. gypseum, and T. mentagrophytes, as shown in Table 3.

Table 3. Antifungal properties of essential oils produced by hydrodistillation of Clinopodium nepeta subsp. nepeta and C. nepeta subsp. glandulosum (MIC, $\mathrm{mg} \cdot \mathrm{mL}^{-1}$ ).

\begin{tabular}{cccc}
\hline Fungal Strains & \multicolumn{3}{c}{ Essential Oils } \\
\cline { 2 - 4 } & $\mathbf{C N N}$ & $\mathbf{C N G}_{\mathbf{1}}$ & CNG $_{\mathbf{2}}$ \\
\hline Aspergillus flavus & 2 & 2 & $>2$ \\
Aspergillus terreus & 0.4 & 0.4 & 0.4 \\
Candida albicans & 0.2 & 0.2 & 0.4 \\
Microsporum canis & 0.4 & 0.4 & 0.4 \\
Microsporum gypseum & 0.2 & 0.4 & 0.4 \\
Trichophyton mentagrophytes & 0.2 & 0.04 & 0.4 \\
\hline
\end{tabular}

In general terms, the tested fungal isolates showed a variable degree of sensitivity patterns to the selected essential oils. The Minimal Inhibitory Concentrations (MIC) ranged from 0.04 to $2 \mathrm{mg} \cdot \mathrm{mL}^{-1}$. It was found that $A$. terreus and M. canis molds were moderately sensitive to all tested samples exhibiting 
a MIC value of $0.4 \mathrm{mg} \cdot \mathrm{mL}^{-1}$. It is relevant to note that the $\mathrm{CNG}_{1}$ essential oil was considerably able to inhibit the fungal growth rate of T. mentagrophytes dermatophyte (MIC $=0.04 \mathrm{mg} \cdot \mathrm{mL}^{-1}$ ).

Moreover, the results showed that the $\mathrm{CNN}$ essential oil was a little bit more effective on $M$. gypseum when compared to $\mathrm{CNG}_{1}$ and $\mathrm{CNG}_{2}$ samples (MIC equal to $0.2 \mathrm{vs.} 0.4 \mathrm{mg} \cdot \mathrm{mL}^{-1}$, respectively). On the other hand, $\mathrm{CNG}_{2}$ essential oil was less effective on the yeast $C$. albicans, with a MIC value of $0.4 \mathrm{mg} \cdot \mathrm{mL}^{-1}$.

\subsection{Insecticidal Activity of the Test Oils}

The repellent properties of the three C. nepeta essential oils against T. confusum and S. zeamais adults were tested using the McDonald method. Table 4 gives the average repellency values of the essential oils tested at $2 \%$ concentration and for different exposure times.

Table 4. Repellency and toxicity of Tribolium confusum and Sitophilus zeamais exposed to the C. nepeta subspecies essential oils ( $2 \%$ and $5 \%$ concentrations for repellency and mortality tests, respectively) [A].

\begin{tabular}{|c|c|c|c|c|c|}
\hline \multirow{2}{*}{$\begin{array}{l}\text { Essential Oils } \\
\text { Plant Source }\end{array}$} & \multirow{2}{*}{$\begin{array}{c}\text { Exposure } \\
\text { Duration (min) }\end{array}$} & \multicolumn{2}{|c|}{ Repellency (\%) } & \multicolumn{2}{|c|}{ Mortality (\%) } \\
\hline & & T. confusum & S. zeamais & T. confusum & S. zeamais \\
\hline \multirow{4}{*}{$\mathrm{CNN}$} & 15 & $52.5 \pm 9.57^{a}$ & $22.5 \pm 9.57^{\mathrm{a}}$ & \multirow{4}{*}{$35 \pm 5.00^{b}$} & \multirow{4}{*}{$32.5 \pm 5.00^{a}$} \\
\hline & 30 & $52.5 \pm 5.00^{\mathrm{a}}$ & $40 \pm 8.16^{\mathrm{a}}$ & & \\
\hline & 60 & $55 \pm 5.77^{a}$ & $57.5 \pm 9.57^{\mathrm{a}}$ & & \\
\hline & 120 & $57.5 \pm 18.92^{a}$ & $57.5 \pm 9.57^{a}$ & & \\
\hline \multirow{4}{*}{$\mathrm{CNG}_{1}$} & 15 & $82.5 \pm 9.57^{b}$ & $60 \pm 11.54^{b}$ & \multirow{4}{*}{$17.5 \pm 8.00^{\mathrm{a}}$} & \multirow{4}{*}{$100 \pm 0.00^{b}$} \\
\hline & 30 & $85 \pm 10.00^{b}$ & $62.5 \pm 9.57^{b}$ & & \\
\hline & 60 & $92.5 \pm 5.00^{b}$ & $92.5 \pm 9.57^{b}$ & & \\
\hline & 120 & $95 \pm 5.77^{b}$ & $92.5 \pm 5.00^{b}$ & & \\
\hline \multirow{4}{*}{$\mathrm{CNG}_{2}$} & 15 & $80 \pm 18.25^{b}$ & $87.5 \pm 18.92^{b}$ & \multirow{4}{*}{$17.5 \pm 5.00^{\mathrm{a}}$} & \multirow{4}{*}{$97.5 \pm 5.00^{b}$} \\
\hline & 30 & $80 \pm 8.16^{b}$ & $87.5 \pm 5.00^{c}$ & & \\
\hline & 60 & $82.5 \pm 9.57^{b}$ & $90 \pm 0.00^{b}$ & & \\
\hline & 120 & $87.5 \pm 5.00^{b}$ & $92.5 \pm 9.57^{b}$ & & \\
\hline
\end{tabular}

[A] Data are mean \pm SE $(n=4)$. Means with same alphabetic letters are not significantly different at $p<0.01$ using Tukey's HSD test between essential oil plant sources for the same exposure duration and same insect species.

We noticed that the repellent activity increased with a prolonged exposure time and varied depending on the tested sample. Thus, both populations of Clinopodium nepeta subsp. glandulosum $\left(\mathrm{CNG}_{1}\right.$ and $\left.\mathrm{CNG}_{2}\right)$ had a prominent repellency effect against both insects (PR $>80 \%$, after $2 \mathrm{~h}$ ), while C. nepeta subsp. nepeta displayed a significantly low activity $(\mathrm{PR}<60 \%$, after $2 \mathrm{~h}),\left(F_{d f 2,11}=11.3\right.$; $p=0.003$ for $T$. confusum and $F_{d f 2,11}=23.5 ; p<0.00$ for S. zeamais).

Data presented in Table 4 showed that the tested oils exhibited, at $5 \%$ concentration, various degrees of toxicity against $T$. confusum and $S$. zeamais after $24 \mathrm{~h}$ exposure.

Using topical application bioassay, $\mathrm{CNG}_{1}$ and $\mathrm{CNG}_{2}$ essential oils were highly toxic to $S$. zeamais, inducing a mortality rate ranging from $97.5 \%$ for $\mathrm{CNG}_{2}$ to $100 \%$ for $\mathrm{CNG}_{1}$, respectively. However, they were weakly toxic to $T$. confusum ( $17.5 \%$ for both essential oils) $\left(F_{d f 2,11}=8.16 ; p=0.009\right)$.

On the other hand, the $\mathrm{CNN}$ essential oil induced moderate toxicity towards both adult species, with mortality rate values of $35 \%$ and $32.5 \%$ on $T$. confusum and $S$. zeamais, respectively $\left(F_{d f 2,11}=351.5\right.$; $p<0.001)$.

\section{Discussion}

The main purpose of this study was to investigate for the first time the phytochemical variability in Tunisian C. nepeta essential oils taking into consideration the subspecies nepeta and glandulosum and their environmental origin (Béni-M'tir and Bizerta), and consequently its effect on the biological properties. As shown in Table 1, C. nepeta subsp. nepeta and subsp. glandulosum essential oils were mostly characterized by high contents of piperitone oxide and piperitenone oxide. Though the type oil resemblance between the subspecies, some quantitative and qualitative differences have 
been highlighted. Importantly, piperitone oxide which ranks first in CNN essential oil (51.7\%), was identified as the second most abundant phytochemical (23.5\%) in $\mathrm{CNG}_{1}$ after piperitenone oxide (39.3\%). Nonetheless, the monoterpene piperitone ranks second in frequency in $\mathrm{CNG}_{2}$ population (19.5\%) and was totally absent in the remaining analyzed samples. Some reports stated a strong relationship between the variability of $C$. nepeta essential oil chemical compositions and the geographical origin, environmental conditions and the vegetative state of the plants [31,35,36].

Thus, the observed variability in essential oil compositions is probably due to the various intrinsic genetic factors between the subspecies and different environmental aspects such as altitude and climate for both glandulosum subspecies collected in Bizerta and Béni-M'tir [37].

The literature data emphasized a great intraspecific variability of the natural volatile constituents of C. nepeta subsp. nepeta and subsp. glandulosum [30,32]. However, according to some authors, the chemical composition is independent of the subspecies nepeta or glandulosum as both constitute common sources of terpenoids and may produce the same major volatiles with the C-3 oxygenated $p$-menthane skeleton $[33,38]$. Others demonstrated a taxonomic understanding of the subspecies [39].

Some interesting observations were made on the diversity of the secondary metabolism of $C$. nepeta essential oils. Almost three types of volatile oils can be distinguished with some exceptions [40]. The first and most popular one consists mainly of pulegone associated with other cyclohexanones as menthone and piperitenone, along with piperitone oxide and piperitenoneoxide. The second kind of essential oil obtained from Clinopodium taxa is characterized by the predominance of piperitenone and/or of piperitone oxides, with the last one correlated with the presence of iso-pulegone and 1,8-cineole [32].

Thus, it is interesting to note that the essential oils of C. nepeta subsp. nepeta and subsp. glandulosum growing in Tunisia belong to the second type reported in literature as they were rich in piperitone oxide and piperitenone oxide. The compositions of the studied samples are almost similar to those of C. nepeta collected in Corsica [21].

Due to their safety characteristics and various aromatherapeutic effects, essential oils have got a lot of attention in several fields of modern chemistry to treat patients and as environmentally friendly preservatives. In this regard, we evaluated the antifungal activities of the aforementioned essential oils, taking into consideration the effect of the chemical polymorphism on the pharmacological effects of essential oils.

Using the micro-dilution assay, the screening revealed that the antifungal effectiveness of all tested oils differs depending on the chemical composition as well as the dissimilarity of target fungus.

The most important effect was recorded by $\mathrm{CNG}_{1}$ essential oil on $T$. mentagrophytes $(\mathrm{MIC}=0.04 \mathrm{mg} / \mathrm{mL})$. In contrast, the $\mathrm{CNG}_{2}$ oil was less effective on this dermatophyte $(\mathrm{MIC}=0.4 \mathrm{mg} / \mathrm{mL})$, along with A. flavus (MIC $>2 \mathrm{mg} / \mathrm{mL})$ and C. albicans (MIC $=0.4 \mathrm{mg} / \mathrm{mL})$.

The differences may be related to the diversity of their chemical composition and the good antifungal effect of $\mathrm{CNG}_{1}$ essential oil against T. mentagrophytes may be due to the high amount of piperitenone oxide and piperitone oxide. Moreover, we suggest that the lower action of $\mathrm{CNG}_{2}$ oil against the same dermatophyte is due to the antagonist effect of piperitone quantified at a percentage of $19.5 \%$ in this volatile oil.

In the present study, A. flavus was the most resistant for all tested oils. Similarly and accordingly with previous reports, this mold presented the highest MIC value for C. nepeta subsp. nepeta essential oil from Portugal $\left(\mathrm{MIC}=10 \mu \mathrm{L} \cdot \mathrm{mL}^{-1}\right)$ [31].

Moreover, CNN essential oil appeared to be the most effective on the dermatophyte M. gypseum showing the presence of compounds with known antifungal activity as the highly detected piperitone oxide $(51.7 \%)$.

Similarly, previous studies confirmed the high antifungal activity of C. nepeta subsp. nepeta essential oil, especially against Aspergillus and dermatophyte molds [31]. After screening, the Italian C. nepeta volatile oil gave significant MIC values $\left(0.32-1.25 \mu \mathrm{L} \cdot \mathrm{mL}^{-1}\right)$ in comparison with the less effective oils extracted in Portugal. 
Herbivorous insects constitute the most exciting targets that facilitate chemical communication and adaptation to the environment. Repellents are substances with an offensive smell or taste, produced to fight off arthropod insect and to prevent attack from phytophagous. The uses of aromatic herbs and essential oils as insect repellents, has a long history in the herbal folklore [41].

This study represents the first report on the insecticidal efficacy of $C$. nepeta subspecies against T. confusum and S. zeamais.

The results showed that the repellent action was dependent upon the subspecies nepeta or glandulosum, while no significant differences were detected between the ability of both samples of glandulosum subspecies collected in Bizerta and Béni-M'tir regions to repel or kill the insects. Using the McDonald method, both essential oils at a concentration of $2 \%$ showed almost the same repellent activity against $T$. confusum and S. zeamais adults after $2 \mathrm{~h}$ of exposure. The percentages of repellency were 95 and $87.5 \%$ for $\mathrm{CNG}_{1}$ and $\mathrm{CNG}_{2}$, respectively, on T. confusum and $92.5 \%$ for both essential oils on S. zeamais. These oils fall under repellency class V (Highly Repulsive) according to Jilani and $\mathrm{Su}$. [42]. However, $57.5 \%$ repellency of $C$. nepeta subsp. nepeta essential oil was observed against both adult insects, thus the volatile oil falls under class III repellency (Moderately Repulsive).

Our results are in line with the repellent efficacy of C. nepeta essential oil towards Aedes aegypti mosquito. For instance, the essential oil gave promising scores for both space repellent properties and olfactory studies carried out on human volunteers [43].

Using the topical application bioassay, the application of these essential oils, at a concentration of $5 \%$, resulted in mortality of T. confusum and S. zeamais within $24 \mathrm{~h}$ of exposure.

$\mathrm{CNN}$ essential oil was moderately toxic against both $T$. confusum and $S$. zeamais, whereas $\mathrm{CNG}_{1}$ and $\mathrm{CNG}_{2}$ essential oils were extremely toxic against $S$. zeamais. The mortality rate was 100 and $97.5 \%$, respectively, after $24 \mathrm{~h}$ of exposure. For T. confusum, the mortality rate caused by glandulosum subspecies was $17.5 \%$. Thus, the $\mathrm{CNG}_{1}$ and $\mathrm{CNG}_{2}$ essential oils presented a weaker activity against T. castaneum compared to the oil from the Montenegro accession of $C$. nepeta subsp. glandulosum, which showed mortality rates of 56.7 and $96.7 \%$ after 24 and $96 \mathrm{~h}$ of treatment, respectively. [27].

Previous literature data attributed the insecticidal properties of many essential oils to monoterpenoids, mainly the oxygenated ones, which are typically volatile compounds that can penetrate rapidly into the insects and interfere with their physiological functions [41,44].

Actually, the antifungal, repellent and insecticidal assays put in evidence that $\mathrm{CNG}_{1}$ essential oil was the most active one. This oil was characterized by the highest percentages of piperitenone oxide (39.3 vs. 23.4 and $27.8 \%$ of $\mathrm{CNN}$ and $\mathrm{CNG}_{2}$, respectively). This monoterpenoid, endowed with an epoxide group, is typical of several Mentha L. essential oils, for instance M. longifolia L., M. suaveolens Ehrh. and M. microphylla K. Koch, which have demonstrated significant toxicity against stored product insects and fungal species [45-47]. Its biological power is given by the epoxide ring, which is interacting with proteins, neurotransmitters and nucleic acids [48]. Furthermore, piperitone oxide has been reported as a toxic repellent and reproduction retardant secondary metabolite towards the malarial vector Anopheles stephensi [49] as well as an effective antimicrobial agent [45]. In the present study, the $C$. nepeta subspecies oils showed differences in the activity against T. confusum and S. zeamais. Thus, repellent and toxic effects of the tested essential oils depend on the chemical composition variability as well as the insect susceptibility.

\section{Materials and Methods}

\subsection{Plant Material and Essential Oils Distillation}

The aerial parts of well-selected individuals from two native $C$. nepeta subspecies, i.e., subsp. nepeta and subsp. glandulosum, were harvested during the flowering stages from different regions/localities in North and North-Western of Tunisia (Table 1). Botanical identification of uninfected plant materials was authenticated by Dr. Ridha El Mokni, affiliated to the Department of Pharmaceutical Sciences " $A$ ", Laboratory of Botany, Cryptogamy and Plant Biology, Faculty of Pharmacy of Monastir, Tunisia, where 
the voucher specimens have been preserved (Table 1). A quantity of $100 \mathrm{~g}$ of each sample was subjected to hydrodistillation in a glass Clevenger-type apparatus for $3 \mathrm{~h}$. The oily fraction obtained on top of the aqueous phase at the end of each extraction was separated, dried over anhydrous sodium sulfate, filtered, and stored in the refrigerator until further analysis. The extraction yields were estimated on a dry weight basis $(w / w)$.

\subsection{Gas Chromatography-Mass Spectrometry (GC-MS)}

Analyses of essential oil chemical compositions were performed using an Agilent 7890B gas chromatograph equipped with an auto sampler (PAL RSI 85) and coupled to a 5977B single quadrupole mass analyzer (Santa Clara, Californy, USA). Injection of $1 \mu \mathrm{L}$ of the diluted sample (1:2000 dilution) in $n$-hexane (Carlo Erba, Milan, Italy) in the front inlet set at $280{ }^{\circ} \mathrm{C}$ was performed in split mode (1:100) with a split flow of $120 \mathrm{~mL} / \mathrm{min}$ using an Agilent 5190-3983 liner (800 $\mu \mathrm{L})$. Separation was performed using a $30 \mathrm{~m} \times 0.25 \mathrm{~mm}$ i.d. $\times 0.25 \mu \mathrm{m}$ film thickness, $5 \%$ phenylmethylpolysiloxane, HP-5MS capillary column (Agilent, Folsom, CA, USA) and helium (99.99\%) was the carrier gas flown at $1.2 \mathrm{~mL} / \mathrm{min}$. The following oven temperature program was used: $60{ }^{\circ} \mathrm{C}$ for $5 \mathrm{~min}$, then $4{ }^{\circ} \mathrm{C} / \mathrm{min}$ up to $160^{\circ} \mathrm{C}$, then $11^{\circ} \mathrm{C} / \mathrm{min}$ up to $280^{\circ} \mathrm{C}$ with a hold time of $15 \mathrm{~min}$, and finally $15^{\circ} \mathrm{C} / \mathrm{min}$ until $300^{\circ} \mathrm{C}$ for a total run time of $57.74 \mathrm{~min}$. MSD transfer line temperature was set at $300^{\circ} \mathrm{C}$. Analysis was made in electron impact (EI) mode (internal ionization source; $70 \mathrm{eV}$ ) with a scan range from 29 to $400 \mathrm{~m} / \mathrm{z}$, after a solvent delay of $2.5 \mathrm{~min}$. The compounds were identified by two approaches: (i) correspondence of retention indices (RIs) reported in libraries [50] (NIST 17, 2017; FFNSC 2, 2012) with the ones calculated using a mixture of n-alkanes $\left(\mathrm{C}_{8}-\mathrm{C}_{30}\right.$, Supelco, Bellefonte, $\left.\mathrm{CA}, \mathrm{USA}\right)$; (ii) comparison of the obtained mass spectra with those stored in libraries (WILEY275, ADAMS, NIST 17 and FFNSC 2); (iii) co-injection with available analytical standards. The chromatograms have been integrated and the relative abundance (\%) of each compound was obtained $(\%=100 \times$ peakarea/totalpeakarea $)$. The repeatability is expressed by coefficient of variation (CV)\% obtained performing the GC/MS analyses in triplicate of the different samples. The coefficient of variation obtained ranged from $0.3 \%$ to $5.8 \%$. The inter-day repeatability of the GC/MS method was determined by 3-day replicate analyses of volatiles, evaluated on the same aliquot of sample stored in the refrigerator, $\mathrm{CV} \%$ ranged from $0.1 \%$ to $3.9 \%$, accounting for very high constant results.

\subsection{Antifungal Activity}

\subsubsection{Fungal Isolates}

The antifungal effectiveness of $C$. nepeta subspecies essential oils was tested against the animal source dermatophytes: Microsporum canis, Microsporum gypseum and Trichophyton mentagrophytes, the environmental origin molds: Aspergillus flavus, Aspergillus terreus and the yeast Candida albicans.

\subsubsection{Microdilution Test}

The antifungal susceptibility tests were carried out using a microdilution assay, according to the Clinical and Laboratory Standards Institute (CLSI) M38 $\mathrm{A}_{2}$ recommendations for molds [51], and those of CLSI M27A 3 for yeasts [52]. Essential oils were assayed at different concentrations $(2,1.8,1.6,1.4$, $1.2,1,0.8,0.6,0.4,0.2,0.08,0.06,0.04$, and $0.02 \mathrm{mg} / \mathrm{mL}$ ). All procedures were performed in triplicate.

\subsection{Insecticidal Activity}

\subsubsection{Tested Insects and Rearing Conditions}

Tribolium confusum and Sitophilus zeamais were taken from the Laboratory of Entomology, Regional Research Center on Horticulture and Organic Agriculture, Chott-Mariem (CRRHAB), Tunisia. Insect adults were cultured in a growth cabinet set at the following rearing conditions: $28 \pm 1{ }^{\circ} \mathrm{C}, 60 \%$ relative 
humidity (RI), $16 \mathrm{~h}$ light and $8 \mathrm{~h}$ dark photoperiod, without exposure to any insecticidal contamination. The food media used were wheat flour for T. confusum and whole maize grains for S. zeamais.

\subsubsection{Repellent Activity}

The repellency test against $T$. confusum and S. zeamais beetle adults was assessed following McDonald et al. [53] method. Briefly, $200 \mu \mathrm{L}$ of each essential oil solution, adjusted at a concentration of $2.0 \%$, were applied to a half Whatman filter paper (No.1) disc of $9 \mathrm{~cm}$ diameter. The other half, used as a control, was steeped with $200 \mu \mathrm{L}$ of pure acetone. After air-drying for $10 \mathrm{~min}$, treated and untreated halves were attached together. Then, 20 adult insects of both species were released separately at the center of the filter paper disc then placed into Petri dishes. After 15, 30, 60, and 120 min from the beginning of the assay the numbers of insects present on the control $(\mathrm{Nc})$ and on the treated $(\mathrm{Nt})$ areas were registered. Each experiment was performed in four repetitions. The repellency percentage values (PR) were computed as follows:

$$
\mathrm{PR}=[(\mathrm{Nc}-\mathrm{Nt}) /(\mathrm{Nc}+\mathrm{Nt})] \times 100
$$

The resulting values were used for the classification of essential oils in different repellency classes suggested by Jilani and Su [42].

\subsubsection{Contact Toxicity: Topical Application Bioassay}

C. nepeta subspecies essential oils were tested against T. confusum and S. zeamais following the method of Liu and Ho [54]. Aliquots of $1 \mu \mathrm{L}$ from each sample at $5 \%$ concentration (10 $\mu \mathrm{L}$ of each EO dissolved in acetone) were topically applied on the thorax of insect adults using a micropipette. Insect controls were treated only with acetone. After evaporating the solvent, groups of 10 adults were introduced on glass Petri dishes ( $9 \mathrm{~cm}$ diameter). Four repetitions were carried out for each experiment. Petri dishes were kept under the same rearing conditions described above and insects mortality was recorded after $24 \mathrm{~h}$ of treatment (until the number of dead insects stabilized). Insects that did not record any movements were considered as dead. Abbott's formula [55] was used to correct the mortality rate:

$$
\% \mathrm{Mc}=[(\mathrm{M} 0-\mathrm{Mt}) /(100-\mathrm{Mt})] \times 100
$$

where Mc: Corrected mortality rate; and $\mathrm{M}_{0}$ and Mt: Mortality rate of treated and control insects, respectively.

\subsubsection{Data Analysis}

Statistical analyses were performed using ANOVA followed by Tukey'HSD test. SPSS 20 software was used to perform all tests.

\section{Conclusions}

The obtained results showed that Clinopodium nepeta subsp. nepeta and C. nepeta subsp. glandulosum essential oils presented chemical variability depending on the subspecies and the geographical location of plant materials. The monoterpenoid-rich essential oils demonstrated high antifungal activities against dermatophytes, molds and yeasts with different efficiencies. Given the pronounced repellent and toxic effects towards T. confusum and S. zeamais, C. nepeta subsp. glandulosum oils may be considered as promising candidates to control those insect pests during storage. To better understand the pharmacological effects of the analyzed samples, further investigation on the effective major compounds will be carried out. Added to that, an exploration of the synergistic interactions, the antagonist effects and the environmental safety is imperative before suggesting them as fungal drugs or safe alternatives to grain protectants. 
Author Contributions: H.D.; preparation of essential oils and performance of insecticidal tests; R.E.M.; plants selection, collection and identification. I.C.; supervision of insecticidal tests; S.N.; performance of antifungal tests; F.M. and G.C.; composition analysis; paper correction and editing.; S.H.; experimental supervision and revision of original draft. All authors have read and agreed to the published version of the manuscript.

Funding: This research received no external funding.

Conflicts of Interest: The authors declare no conflict of interest.

\section{References}

1. Boyer, S.; Zhang, H.; Lempérière, G. A review of control methods and resistance mechanisms in stored-product insects. Bull. Entomol. Res. 2012, 102, 213-229. [CrossRef]

2. Pavela, R. Essential oils for the development of eco-friendly mosquito larvicides: A review. Ind. Crops Prod. 2015, 76, 174-187. [CrossRef]

3. Abdel-Kawy, M.A.; Michel, C.G.; Kirollos, F.N.; Hussien, R.A.A.; Al-Mahallawi, A.M.; Sedeek, M.S. Chemical composition and potentiation of insecticidal and fungicidal activities of Citrus trifoliata L. fruits essential oil against Spodoptera littoralis, Fusarium oxysporum and Fusarium solani via nano-cubosomes. Nat. Prod. Res. 2019, 1-6. [CrossRef] [PubMed]

4. Rezgui, M.; Majdoub, N.; Mabrouk, B.; Baldisserotto, A.; Bino, A.; Ben Kaab, L.B.; Manfredini, S. Antioxidant and antifungal activities of marrubiin, extracts and essential oil from Marrubium vulgare L. against pathogenic dermatophyte strains. J. Mycol. Med. 2020, 30, 100927. [CrossRef] [PubMed]

5. Benelli, G.; Pavela, R.; Zorzetto, C.; Sánchez-Mateo, C.C.; Santini, G.; Canale, A.; Maggi, F. Insecticidal activity of the essential oil from Schizogyne sericea (Asteraceae) on four insect pests and two non-target species. Entomol. Gen. 2019, 39, 9-18. [CrossRef]

6. Pavela, R.; Maggi, F.; Iannarelli, R.; Benelli, G. Plant extracts for developing mosquito larvicides: From laboratory to the field, with insights on the modes of action. Acta Trop. 2019, 193, 236-271. [CrossRef]

7. Benelli, G.; Maggi, F.; Canale, A.; Mehlhorn, H. Lyme disease is on the rise-How about tick repellents? A global view. Entomol. Gen. 2019, 39, 61-72. [CrossRef]

8. Benelli, G.; Pavela, R. Repellence of essential oils and selected compounds against ticks-A systematic review. Acta Trop. 2018, 179, 47-54. [CrossRef]

9. Ramezani, S.; Rahmanian, M.; Jahanbin, R.; Mohajeri, F.; Reza Rezaei, M.; Solaimani, B. Diurnal Changes in Essential Oil Content of Coriander (Coriandrum sativum L.) Aerial Parts from Iran. Res. J. Biol. Sci. 2009, 4, 277-281.

10. Mishra, R.; Gupta, A.K.; Kumar, A.; Lal, R.K.; Saikia, D.; Chanotiya, C.S. Genetic diversity, essential oil composition, and in vitro antioxidant and antimicrobial activity of Curcuma longa L. germplasm collections. J. Appl. Res. Med. Aromat. Plants 2018, 10,1-10. [CrossRef]

11. Santos, V.M.C.S.; Pinto, M.A.S.; Bizzo, H.; Deschamps, C. Seasonal variation of vegetative growth, essential oil yield and composition of menthol mint genotypes at southern brazil. Biosci. J. 2012, 28, 790-798.

12. Noroozisharaf, A.; Kaviani, M. Effect of soil application of humic acid on nutrients uptake, essential oil and chemical compositions of garden thyme (Thymus vulgaris L.) under greenhouse conditions. Physiol. Mol. Biol. Plants 2018, 24, 423-431. [CrossRef] [PubMed]

13. Dunkić, V.; Kremer, D.; Jurišić Grubešić, R.; Vuković Rodríguez, J.; Ballian, D.; Bogunić, F.; Stešević, D.; Kosalec, I.; Bezić, N.; Stabentheiner, E. Micromorphological and phytochemical traits of four Clinopodium L. species (Lamiaceae). South African J. Bot. 2017, 111, 232-241.

14. Castilho, P.; Liu, K.; Rodrigues, A.I.; Feio, S.; Tomi, F.; Casanova, J. Composition and antimicrobial activity of the essential oil of Clinopodium ascendens (Jordan) Sampaio from Madeira. Flavour Fragr. J. 2007, 22, 139-144. [CrossRef]

15. Moattar, F.S.; Sariri, R.; Giahi, M.; Yaghmaee, P. Essential oil composition and antioxidant activity of Calamintha officinalis Moench. J. Appl. Biotechnol. Rep. 2018, 5, 55-58. [CrossRef]

16. Hidalgo, P.J.; Libera, J.L.; Santos, J.A.; LaFont, F.; Castellanos, C.; Palomino, A.; Román, M. Essential oils in Calamintha sylvatica Bromf. ssp. ascendens (Jordan) P.W. Ball: Wild and cultivated productions and antifungal activity. J. Essent. Oil Res. 2002, 14, 68-71. [CrossRef] 
17. Li, H.Y.; Liu, X.C.; Chen, X.B.; Liu, Q.Z.; Liu, Z.L. Chemical composition and insecticidal activities of the essential oil of Clinopodium chinense (Benth.) kuntze aerial parts against Liposcelis bostrychophila Badonnel. J. Food Prot. 2015, 78, 1870-1874. [CrossRef]

18. Motti, R.; Ippolito, F.; Bonanomi, G. Folk Phytotherapy in Paediatric Health Care in Central and Southern Italy: A Review. Hum. Ecol. 2018, 46, 573-585. [CrossRef]

19. Khodja, N.K.; Boulekbache, L.; Chegdani, F.; Dahmani, K.; Bennis, F.; Madani, K. Chemical composition and antioxidant activity of phenolic compounds and essential oils from Calamintha nepeta L. J. Complement. Integr. Med. 2018, 15, 1-12. [CrossRef]

20. Božović, M.; Ragno, R. Calamintha nepeta (L.) Savi and its main essential oil constituent Pulegone: Biological activities and chemistry. Molecules 2017, 22, 290. [CrossRef]

21. Baldovini, N.; Ristorcelli, D.; Tomi, F.; Casanova, J. Intraspesific variability of the essential oil of Calamintha nepeta from Corsica (France). Flavour Fragr. J. 2000, 15, 50-54. [CrossRef]

22. Araniti, F.; Lupini, A.; Sorgonà, A.; Statti, G.A.; Abenavoli, M.R. Phytotoxic activity of foliar volatiles and essential oils of Calamintha nepeta (L.) Savi. Nat. Prod. Res. 2013, 27, 1651-1656. [CrossRef] [PubMed]

23. Mancini, E.; De Martino, L.; Malova, H.; De Feo, V. Chemical composition and biological activities of the essential oil from Calamintha nepeta plants from the wild in southern Italy. Nat. Prod. Commun. 2013, 8, 139-142. [CrossRef] [PubMed]

24. Kitic, D.; Jovanovic, T.; Ristic, M.; Palic, R.; Stojanovic, G. Chemical composition and antimicrobial activity of the essential oil of Calamintha nepeta (L.) Savi ssp. glandulosa (Req.) P.W. Ball from Montenegro. J. Essent. Oil Res. 2002, 14, 150-152. [CrossRef]

25. Sarac, N.; Ugur, A. The In Vitro Antimicrobial Activities of the Essential Oils of Some Lamiaceae Species from Turkey. J. Med. Food 2009, 12, 902-907. [CrossRef] [PubMed]

26. Božovic, M.; Garzoli, S.; Sabatino, M.; Pepi, F.; Baldisserotto, A.; Andreotti, E.; Romagnoli, C.; Mai, A.; Manfredini, S.; Ragno, R. Essential oil extraction, chemical analysis and anti-Candida activity of Calamintha nepeta (L.) Savi subsp. glandulosa (Req.) Ball-New approaches. Molecules 2017, 22, 1-12.

27. Popović, A.; Šućur, J.; Orčić, D.; Štrbac, P. Effects Of Essential Oil Formulations On The Adult Insect Tribolium Castaneum (Herbst) (Col., Tenebrionidae). J. Cent. Eur. Agric. 2013, 14, 181-193. [CrossRef]

28. Conforti, F.; Marrelli, M.; Statti, G.; Menichini, F.; Uzunov, D.; Solimene, U.; Menichini, F. Comparative chemical composition and antioxidant activity of Calamintha nepeta (L.) Savi subsp. glandulosa (Req.) Nyman and Calamintha grandiflora (L.) Moench (Labiatae). Nat. Prod. Res. 2012, 26, 91-97. [CrossRef]

29. Ambrico, A.; Trupo, M.; Martino, M.; Sharma, N. Essential oil of Calamintha nepeta (L.) Savi subsp. nepeta is a potential control agent for some postharvest fruit diseases. Org. Agric. 2019, 10, 35-48. [CrossRef]

30. Vlachou, G.; Papafotiou, M.; Bertsouklis, K.F. Studies on Seed Germination and Micropropagation of Clinopodium nepeta: A medicinal and aromatic plant. HortScience 2019, 54, 1558-1564. [CrossRef]

31. Marongiu, B.; Piras, A.; Porcedda, S.; Falconieri, D.; Maxia, A.; Goncalves, M.J.; Cavaleiro, C.; Salgueiro, L. Chemical composition and biological assays of essential oils of Calamintha nepeta (L.) Savi subsp. nepeta (Lamiaceae). Nat. Prod. Res. 2010, 24, 1734-1742. [CrossRef] [PubMed]

32. Arantes, S.M.; Piçarra, A.; Guerreiro, M.; Salvador, C.; Candeias, F.; Caldeira, A.T.; Martins, M.R. Toxicological and pharmacological properties of essential oils of Calamintha nepeta, Origanum virens and Thymus mastichina of Alentejo (Portugal). Food Chem. Toxicol. 2019, 133, 110747. [CrossRef] [PubMed]

33. Kitic, D.; Stojanovic, G.; Palic, R.; Randjelovic, V. Chemical Composition and Microbial Activity of the Essential Oil of Calamintha nepeta (L.) Savi ssp. nepeta var. subisodonda (Borb.) Hayek from Serbia. J. Essent. Oil Res. 2005, 17, 701-703. [CrossRef]

34. Espina, L.; Somolinos, M.; Lorán, S.; Conchello, P.; García, D.; Pagán, R. Chemical composition of commercial citrus fruit essential oils and evaluation of their antimicrobial activity acting alone or in combined processes. Food Control 2011, 22, 896-902. [CrossRef]

35. Ćavar, S.; Vidic, D.; Maksimović, M. Volatile constituents, phenolic compounds, and antioxidant activity of Calamintha glandulosa (Req.) Bentham. J. Sci. Food Agric. 2013, 93, 1758-1764. [CrossRef]

36. Ristorcelli, D.; Tomi, F.; Casanova, J. Essential oils of Calamintha nepeta subsp. nepeta and subsp. glandulosa from Corsica (France). J. Essent. Oil Res. 1996, 8, 363-366. [CrossRef]

37. Şanli, A.; Karadoğan, T. Geographical Impact on Essential Oil Composition of Endemic Kundmannia Anatolica HUB.-MOR. (Apiaceae). African J. Tradit. Complement. Altern. Med. AJTCAM 2017, 14, 131-137. [CrossRef] 
38. De Pooter, L.H.; Goetghebeur, P.; Schamp, N. Variability in composition of the essential oil of Calamintha nepeta. Phytochemistry 1987, 26, 3355-3356. [CrossRef]

39. Fraternale, D.; Giamperi, L.; Ricci, D.; Manunta, A. Composition of essential oil as a taxonomic marker for Calamintha nepeta (L.) Savi ssp. nepeta. J. Essent. Oil Res. 1998, 10, 568-570. [CrossRef]

40. Alan, S.; Kürkçüoglu, M.; Can Baser, K.H. Composition of essential oils of Calamintha nepeta (L.) Savi subsp. nepeta and Calamintha nepeta (L.) Savi subsp. glandulosa (Req.) P.W. Ball. Asian J. Chem. 2011, 23, 2357-2360.

41. Kumar, P.; Mishra, S.; Malik, A.; Satya, S. Insecticidal properties of Mentha species: A review. Ind. Crops Prod. 2011, 34, 802-817. [CrossRef]

42. Jilani, G.; Su, H.C.F. Laboratory Studies on Several Plant Materials as Insect Repellants for Protection of Cereal Grains. J. Econ. Entomol. 1983, 76, 154-157. [CrossRef]

43. Drapeau, J.; Fröhler, C.; Touraud, D.; Kröckel, U.; Geier, M.; Rose, A.; Kunz, W. Repellent studies with Aedes aegypti mosquitoes and human olfactory tests on 19 essential oils from Corsica, France. Flavour Fragr. J. 2009, 24, 160-169. [CrossRef]

44. Bakkali, F.; Averbeck, S.; Averbeck, D.; Idaomar, M. Biological effects of essential oils-A review. Food Chem. Toxicol. 2008, 46, 446-475. [CrossRef] [PubMed]

45. Oumzil, H.; Ghoulami, S.; Rhajaoui, M.; Ilidrissi, A.; Fkih-Tetouani, S.; Faid, M.; Benjouad, A. Antibacterial and antifungal activity of essential oils of Mentha suaveolens. Phytother. Res. 2002, 16, 727-731. [CrossRef] [PubMed]

46. Kavallieratos, N.G.; Boukouvala, M.C.; Ntalli, N.; Skourti, A.; Karagianni, E.S.; Nika, E.P.; Kontodimas, D.C.; Cappellacci, L.; Petrelli, R.; Morshedloo, M.R.; et al. Effectiveness of eight essential oils against two key stored-product beetles, Prostephanus truncatus (Horn) and Trogoderma granarium. Food Chem. Toxicol. 2020, 139, 111255. [CrossRef] [PubMed]

47. Božović, M.; Pirolli, A.; Ragno, R. Mentha suaveolens Ehrh. (Lamiaceae) essential oil and its main constituent piperitenone oxide: Biological activities and chemistry. Molecules 2015, 20, 8605-8633. [CrossRef]

48. Wink, M.; Schimmer, O. Modes of Action of Defensive Secondary Metabolites; Wink, M., Ed.; CRC: Boca Raton, FL, USA, 1999; pp. 17-133.

49. Tripathi, A.K.; Prajapati, V.; Ahmad, A.; Aggarwal, K.K.; Khanuja, S.P.S. Piperitenone Oxide as Toxic, Repellent, and Reproduction Retardant toward Malarial Vector Anopheles stephensi (Diptera: Anophelinae). J. Med. Entomol. 2004, 41, 691-698. [CrossRef]

50. Adams, R.P. Identification of Essential Oil Components by Gas Chromatography/Mass Spectrometry, 4th ed.; Allured Publishing Corporation: Carol Stream, IL, USA, 2007.

51. Wayne, P.A. Clinical and Laboratory Standards Institute (CLSI): Reference Method for Broth Dilution Antifungal Susceptibility Testing of Filamentous Fungi, 2nd ed.; Allured Publishing Corporation: Carol Stream, IL, USA, 2008; pp. M38-A2.

52. Wayne, P.A. Clinical and Laboratory Standards Institute (CLSI): Reference Method for Broth Dilution Antifungal Susceptibility Testing of Yeasts, 3rd ed.; Allured publishing corporation: Carol Stream, IL, USA, 2008; pp. M27-A3.

53. McDonald, L.L.; Guy, R.H.; Speirs, R.D. Preliminary Evaluation of New Candidate Materials as Toxicants, Repellents and Attractants Against Stored Product Insects, Marketing Research Report; Agricultural Research Service, United State Department of Agriculture: Washington, DC, USA, 1970.

54. Liu, Z.L.; Ho, S.H. Bioactivity of the essential oil extracted from Evodia rutaecarpa Hook f. et Thomas against the grain storage insects, Sitophilus zeamais Motsch. and Tribolium castaneum (Herbst). J. Stored Prod. Res. 1999, 35, 317-328. [CrossRef]

55. Abbott, W.S. A method for computing the effectiveness of an insecticidee. J. Econ. Entomol. 1925, 18, $265-267$. [CrossRef]

(C) 2020 by the authors. Licensee MDPI, Basel, Switzerland. This article is an open access article distributed under the terms and conditions of the Creative Commons Attribution (CC BY) license (http://creativecommons.org/licenses/by/4.0/). 